\title{
CALCULATION AND REDUCTION COSTS IN THE ROMANIAN CLOTHING INDUSTRY BY THE DIRECT-COSTING METHOD
}

\author{
Teodora Maria SUCIU (AVRAM) ${ }^{1}$
}

\begin{abstract}
The scientific paper presents a cost calculation system in the clothing industry in Romania based on manufactured goods production, presented in an empirical study to identify ways to reduce production costs. The use of the Direct-Costing method in relation to clothing production provides a high level of responsibility for cost managers in obtaining operative information on the development of the production process and the application of calculation methods for making efficient managerial decisions and the proper management of money resources. The research results from the calculation of indicators specific to the presented method show that CONF Ltd. is exposed to the bankruptcy risk because the volume of sales and the profit related to turnover are low. The results are useful to managers on making the best decisions for business development, profit growth, reducing production cost, achieving profitable investment, and business partners to know the financial situation of the companies with which they collaborate.
\end{abstract}

Keywords: cost calculation, Direct-Costing method, manufactured goods production, cost reduction, economic performance, clothing industry

JEL classification: M41, M49

\section{Introduction}

The clothing industry is of particular importance in the European Union and Romania, as the use of clothing is a strategic objective. The management of the basic activity is characterized by the ways of organizing the production. This is reflected in the clothing industry through serial production or lohn production, which can generate commercial contracts in the form of order processing contracts or in lohn.

Order-based production (Janetta Sârbu, 2005, p. 105) implies certain risks that lead to the reduction of the economic performance of the clothing industry companies that arise due to delays in the transport and supply of raw materials, which may lead to the situation in which the beneficiary considers the collaborating company to be unreliable and to give up the order.

In the clothing industry, in order to make the best decisions, we believe that it is necessary to take into account the following elements (Boris Samochis, Dumitru Purdea, 2007, p. 97):

- the economic objective or well-defined purpose, which can be quantified;

- the large amount of information that reflects the phenomena and economic processes actually taking place in influencing decision-making;

- Data Investigation and Processing Facility, which allows for a rational process.

Decisions taken by managers who use lohn production are taken as a result of consulting the prices and how to settle the lohn operations. In addition, from a tax perspective, managers have to take into account the decision-making process and the peculiarities of the value-added tax on the delivery of lohn production.

1 PhD.,"1 Decembrie 1918” University, Alba Iulia, Faculty of Economic Sciences, Romania, E-mail: teodora.avram@uab.ro

DOI: 10.29302/oeconomica.2019.21.1.6 
Company CONF Ltd. it is real with a fictitious name for confidential reasons. This is a representative company in the Romanian clothing industry, for which we consider it appropriate to draw a detailed analysis of the cost of production using the Direct-Costing method.

\section{Theoretical Framework}

Strategic management of a company is based primarily on knowledge of the costs involved in the production process, in order to optimize managerial decisions on exploitation. Studying the notion of cost as an economic indicator of production and consumption is vast, due to the multiple meaning and connotations it fulfills, that is why we consider it appropriate to point out some opinions that appeared in the literature.

Gheorghe Bistriceanu (2001, p. 461) regards the cost of production as "the economic category specific to the production of the commodity which reflects the objectively arising relations in relation to the commensuration, in monetary terms, of a part of the value of the goods, namely the means of production and the salaries, by an economic unit for the manufacture of a particular product or for the provision of a service."

Our view is that the definition of the cost of production is identified by the relationship between time and space, in the sense that it occurs from the manufacturing process to the final destination of the commodity, therefore it is a source of accounting information specific to time management limited by time; and space-bar.

The Direct-Costing Method (Sorinel Căpuşneanu, 2006, p. 1) consists in "separating the production and selling expenses from their character, in comparison with the physical volume of production and selling, in variable and fixed expenses. Also, unit costs per product are taken into account only for variable and fixed expenses, which are deducted from the gross unit result."

The method presented is representative of the partial cost calculation and represents a stock valuation model that only includes variable production costs in the cost of a unit of output. The full amount of fixed costs is settled from the current year. Consequently, the cost of a product unit in inventory or the cost of goods sold by this method does not contain any fixed cost of costs (Cristina Bunea-Bontaş, 2013, p. 123).

According to Sorin Briciu, Sorinel Căpuşneanu and Andreea Căprăriu (2013, p. 61), the Direct-Costing method focuses on boosting sales by the fact that the size of the fixed costs is not distributed over the stocks - of products under execution, of finished products, of products shipped, but not collected, but should be covered by sales of the period.

Cost reduction is the easiest and surest way to increase your profit in the short term and can also be a major factor in long-term growth if properly managed. Steven Bragg $(2011$, p. 7$)$ is of the opinion that identifying these paths is the simplest way to increase professionalism at company level and cash flow. At the same time, cost reductions also work well for professionals, in the long run, as long as the process becomes a core conviction of the entire company and is constantly redirected. Selecting cost-cutting paths is essential because the long-term cost reduction can not be below the company's profiling capabilities, instead, the focus should be on constantly eliminating unnecessary spending, increasing efficiency and streamlining processes.

The way in which cost reduction is advantageous in the short and long term is explained by Nadica Figar, Vladimir Ivanović (2015, p. 16), which shows that "performing less resourceintensive activities implies greater use of internal reserves, and restructuring value chain requires radical changes that can only be achieved in the long run. " Both actions are implemented through the implementation of different strategies that prioritize the reduction of the different types of costs, among which the first target is almost always considered the cost of the workforce. That is why in practice the reduction of this cost is generally achieved by diminishing the workforce.

Costs have become a growing problem for companies that are increasingly confronted with global competition and bankruptcy, which leads to the need to reduce costs. Researchers in risk reduction analysis (Meenal Kulkarni, Anil Pandit, 2014, p. 482) have found a way for companies to regain control over costs, not just to assess costs, but also to classify and identify in the cost of 
products systematically, and an organized cost-cutting methodology results in an improvement in costs.

\section{Cost calculation system in the clothing industry by the Direct-Costing method}

The determination of the indicators specific to the Direct-Costing method presents at the end the following advantages (Călin O., Man M., Nedelcu M.V., 2008):

- assessing the profitability of different products based on margins on variable costs;

- increased production of products with high margins;

- abandoning products whose margins on variable costs will be negative;

- indication of a minimum price, variable cost, for negotiating an additional order;

- making decisions on how to run businesses when variable costs are lower than prices;

- judging the performance of the managers according to the margin released by sectors;

- establishing forecasts according to the level of activity targeted.

In the performance analysis of the production produced according to the Direct-Costing method (Ion Ionescu, 2013, pp. 37-38) the indicators presented in the following table are used:

Table no. 1. Costs calculation indicators by the Direct-Costing method

\begin{tabular}{|c|c|c|c|}
\hline \multicolumn{2}{|c|}{ Indicator } & Formula & Specification \\
\hline \multirow{2}{*}{$\begin{array}{l}\text { The } \\
\text { equilibrium } \\
\text { point }(\mathrm{Pe})\end{array}$} & $\begin{array}{l}\text { for homogeneous } \\
\text { production }\end{array}$ & $\frac{C F}{C B}$ & \multirow{4}{*}{$\begin{array}{l}\text { It is the point where sales are equal to } \\
\text { variable costs plus fixed costs, or } \\
\text { financial results are null }\end{array}$} \\
\hline & $\begin{array}{l}\text { for heterogeneous } \\
\text { production }\end{array}$ & $\frac{C F}{\overline{C B}}$ & \\
\hline \multirow{2}{*}{\multicolumn{2}{|c|}{ Breakeven (PR) }} & $\frac{C F+D}{1-a}$ & \\
\hline & & $\frac{C F}{1-a}$ & \\
\hline \multicolumn{2}{|c|}{ The coverage factor $(\mathrm{Fa})$} & $\frac{C B}{D} \times 100$ & $\begin{array}{l}\text { Express the percentage of the } \\
\text { contribution of each product to the } \\
\text { fixed costs and the benefit. It directs } \\
\text { the enterprise's decision to the products } \\
\text { with the highest coverage factor }\end{array}$ \\
\hline \multicolumn{2}{|c|}{ Dynamic safety factor (Ks) } & $\frac{P R}{C B} \times 100$ & $\begin{array}{l}\text { Explains how much the sales can } \\
\text { decrease in a relative way for the } \\
\text { company to reach the equilibrium point }\end{array}$ \\
\hline \multicolumn{2}{|c|}{ Safety interval (Is) } & $D-d P e$ & $\begin{array}{l}\text { It expresses in absolute terms the lower } \\
\text { the sales, so the company does not } \\
\text { enter the loss area }\end{array}$ \\
\hline
\end{tabular}

Source: Processing after Sorinel Căpușneanu, 2002. Contabilitate de gestiune și calculația costurilor - Studii aplicative și teste grilă, $\mathrm{I}^{\text {st }}$ Edition, Economică Publishing, București, 2002, pp.

115-116 and Teodor Hada, 1999. Finantele agențiilor economici din România, Intelcredo Publishing, Deva, p. 205.

where: $C F$ - Fixed expense (excluding interest)

$C B$ - Gross contribution (fixed unit costs + unit profit)

$\overline{C B}$ - Average gross contribution $\left(\frac{C B}{\sum q^{i}} \frac{C F}{1-a}\right)$

$q i$ - Production obtained

$D$ - The volume of sales or interest as a fixed expense

$P R$ - Profit 
$d P e$ - Breakout at the point of equilibrium

$a$ - Share of variable costs in fixed costs

In the present study to determine the performance of the manufactured output, we use the cost separation in fixed and variable variables, but because CONF Ltd. does not organize the management accounting, the proposal in this respect is to calculate costs by the Direct Costing method for the semi-finished product variant. We chose this costing method to analyze performance by activity, to ensure rigorous cost control and to highlight what are the most cost-effective products.

The exemplification of the study is to determine the performance indicators provided by the company's accounting records. For this we take into account the volume of sales for 2018, presented in detail according to the calendar months, in table no. 2. We mention that our cost-based research is proposed by us, because the company subject to the case study does not keep accounting records.

Table no. 2. Volume of sales at CONF Ltd.

\begin{tabular}{|l|c|c|}
\multicolumn{1}{|c}{ Month } & $\begin{array}{c}\text { Production of manufactured goods } \\
\text { (turnover 345 in the production price) }\end{array}$ & Turnover (CA) \\
\hline January & $2,498,475$ & $2,998,721$ \\
\hline February & 811,065 & $1,119,215$ \\
\hline March & 758,610 & $3,719,559$ \\
\hline April & $1,485,300$ & $1,608,876$ \\
\hline May & $1,963,740$ & $4,054,224$ \\
\hline June & $2,423,460$ & $3,381,655$ \\
\hline July & $2,276,100$ & $4,151,791$ \\
\hline August & $2,240,160$ & $1,960,539$ \\
\hline September & $1,795,320$ & $3,843,341$ \\
\hline October & $2,893,060$ & $2,948,725$ \\
\hline November & $2,280,600$ & $2,903,559$ \\
\hline December & $1,980,000$ & $2,350,805$ \\
\hline TOTAL 2018 & $\mathbf{2 3 , 4 0 5 , 8 9 0}$ & $\mathbf{3 5 , 0 4 1 , 0 1 0}$ \\
\hline
\end{tabular}

Source: Processing according to the technical-operative and synthetic records of CONF Ltd.

We assert, based on the data in Table 2, that during the months of February-March, it is a poorly productive one compared to the other months. In addition, we note that the production obtained and sold for sale has oscillating values from one month to the next. Therefore, from the analysis of the production of the goods made by the company, we can not exactly say which is the period in which it produces the most, because from one month to the other there are decadence and ascendences. The same oscillating situation is also observed in the evolution of turnover, which can be interpreted by the fact that CONF Ltd. fails to maintain its market share at a high level. We assume that the revenues obtained from the activity of marketing the products produced by the company record values in the normal parameters of the garment industry.

Due to the high volume of work in extracting the expenses from the accounting records for the determination of the indicators in the structure of expenditures, we focus only on one month in 2018. The month for which we chose to perform the analysis is January, for which, based on operative and analytical evidence, we present the structure of the production of goods produced in table no. 3 . 
Tabel no. 3. Total expenditures - January 2018

\begin{tabular}{|l|c|c|c|c|c|}
\hline Indicator & U.M. & $\begin{array}{c}\text { Variable } \\
\text { Expenses (CV) }\end{array}$ & $\begin{array}{c}\text { Fixed costs } \\
(\mathbf{C F})\end{array}$ & $\begin{array}{c}\text { Potential } \\
\text { profit (Pp) }\end{array}$ & TOTAL \\
\hline Value & RON & $2,758,824$ & 209,910 & 29,987 & $2,998,721$ \\
\hline Percent & $\%$ & 92 & 7 & 1 & 100 \\
\hline
\end{tabular}

Source: Processing according to the technical-operative and synthetic records of CONF Ltd.

From an analytical perspective, the percentages of variable and fixed costs fall within the normal range. We believe that the change in variable costs is largely influenced by the production of manufactured goods, which is why its knowledge is very important in studying costs. From table no. 3 it can be seen that the percentage of variable costs is large, which exceeds even $90 \%$ of the total costs. In the variable costs category are included the expenditures on the direct productive staff salaries, and besides, we can also mention the expenditures with the direct materials, the energy expenses, the maintenance expenses, and so on. Since variable costs or production costs are over $70 \%$ in the present case, we believe that in the present study variable costs show normal values.

On the other hand, as a result of our observations, we have come to say that the volume of manufactured goods production is influenced by its growth, by lowering fixed costs. Compared to variable expenditures, fixed expenses remain unchanged and are reflected in CONF Ltd. in rent expenses, salaries of management personnel and administrative staff, wear of inventory items, and so on. Particular attention is paid to the potential profit that the company encompasses in addition to variable and fixed costs in its total turnover. A detailed analysis of fixed costs shows an increase in manufactured goods production, which has led to a decrease in fixed costs, a positive fact, because it is preferable that in the cost analysis the fixed expenses are less than $15 \%$.

In table no. 3 , it is noted that in addition to variable and fixed expenses, the total expenditure also includes the potential profit. Please note that once the output of January 2017 has been delivered, the potential profit of $1 \%$ specific to manufactured goods can be converted to net profit for the year. Once all the necessary data is processed, we present the determination of the DirectCosting method specific indicators. According to this method, we treat variable costs as production costs, and fixed costs as non-production costs, and are therefore considered as expense only for the period.

Table no. 4. Determining cost-calculation indicators using the Direct-Costing method

\begin{tabular}{|c|l|c|c|}
\hline No. crt. & \multicolumn{1}{|c|}{ Indicator } & U.M. & January 2018 \\
\hline \multirow{2}{*}{1} & The equilibrium point & RON & $2,623,880$ \\
\cline { 2 - 4 } & Breakeven & RON & $2,623,875$ \\
\hline $\mathbf{2}$ & The coverage factor & $\%$ & 8 \\
\hline $\mathbf{3}$ & Dynamic safety factor & $\%$ & 12.50 \\
\hline $\mathbf{4}$ & Safety interval & RON & 374,846 \\
\hline $\begin{array}{l}\text { Source: } \\
\text { of manufactured and sold goods by direct costing method, } \\
\text { International Conference "Risk in Contemporary Economy", XIX } \\
\text { Edition and Processing according to Tabel no. 1. }\end{array}$ \\
(n)
\end{tabular}

The equilibrium point shows the volume of sales to be made so as to fully cover the volume of fixed and variable expenses. We point out that the equilibrium point is based on the increase in January 2018 turnover and the reporting of fixed costs to the unit gross contribution. Because economic studies show that the equilibrium point is also referred to as the profitability threshold, which, as a result of the determination, we observe that it is about the same value as the equilibrium point. From the calculation horizon, which is strictly designed for January 2018 at CONF Ltd., the 
profitability threshold is quite high, so the company should try to overcome it in order to increase its profit. Exceeding this point implies that garment manufacturing is cost-effective.

The coverage factor in this case represents the percentage of the contribution of each product to the fixed expenses and the profit. Percentage of coverage factor at CONF Ltd. is $8 \%$, composed of $7 \%$ fixed costs and $1 \%$ potential profit. Therefore, we can say that this factor fully covers fixed costs and potential profit, because its percentage is small.

The dynamic safety factor has helped us to see how much sales can decrease in relative terms, for CONF Ltd. to reach the point of equilibrium. Sales volume according to table no. 4.7, may drop by $12.50 \%$ to reach the equilibrium point, and any drop below this level is a financial imbalance for the company, as it could enter the financial loss area.

By calculating the safety margin, we say that at CONF Ltd. the volume of sales may decrease by 374,846 lei, so the company does not enter the area of losses. At the same time, the analyzed company has a narrow beach of adaptation to the garment market, as the turnover value is close to the profitability threshold, so we can say that the financial situation of the company is a risky one. The risk is also confirmed by the fact that the profit on the turnover is small, only $1 \%$. All these aspects impose the need to look for ways to increase the economic and financial performance at CONF Ltd.

Due to the lack of management accounting for the company under review, the cost calculation study is purely hypothetical and can not be sufficiently detailed due to the lack of sustainable material.

\section{Opportunities to reduce costs to CONF Ltd.}

Following documentation at CONF Ltd. and to other clothing companies, numerous costcutting paths have been identified to increase work productivity for the company's production series. The most important ways to reduce costs to clothing companies are we think that they refer to:

- purchase of samples from production beneficiaries;

- the supply of raw materials and accessories from external suppliers at low prices;

- introducing computer optimized cutting programs to reduce textile consumption (minimizing losses);

- diversification and continuous improvement of assortment in order to attract customers;

- production organized on technological flows depending on the type of operations;

- double operational control: phase and finish with packing;

- the need to introduce technical progress to make the activities of the productive sector more efficient and innovative;

- Increasing labor productivity leading to the reduction of unit wage costs;

- reducing personnel fluctuations due to the high costs that employee replacement requires through recruitment processes, productivity and opportunities that have been lost;

- qualification of employees through vocational training programs such as: "tailor courseassembler of textile articles", "worker in knitwear and clothings";

- employee involvement by rewarding employees in order to stimulate their interests;

- carrying out clothes manufacturing in leased halls, as rent is more cost-effective than building the industrial halls;

We show that a way to reduce costs in the garment industry and implicitly in the company described is the purchase of samples (samples) that are offered by the beneficiaries of the finished products in order to prepare the production, thus CONF Ltd. no longer has to make many attempts to reach the idea proposed by the garment recipient, thus also having the possibility to diversify its assortment without incurring additional costs. 
It has been found that in the materials supply process cost reduction can be achieved by choosing external suppliers of production materials and accessories according to the lowest price offered on the market but also taking into account the relationship between quality and price. Also, given that the materials used by the company described are brought from export, the presence and necessity of transport use is observed. It is therefore necessary to identify those carriers operating at the lowest fares.

As far as the consumption of materials is concerned, they are specified in the production data sheet containing the consumption of raw materials and accessories for each assortment manufactured in accordance with the samples provided by the beneficiary. It is also worth mentioning that the production data sheet also specifies the workmanship as the timing for the manufacture of the assortment. Thus, material consumption and manufacturing time requirements are required to fit the costs set out in the models provided by the beneficiary.

Given that the company's production is organized on the basis of technological flows depending on the type of operations performed, in order to save time, the workforce is assigned to operations according to the specialization of each, as a result of the qualification of the personnel at the workplace through various training programs professional. At the same time, in order to reduce technological losses, the company's management proposed streaming verification through phase control and final control of product packaging. In addition, we propose to introduce technical progress to CONF Ltd. in order to improve the production processes, as well as the economic activity that would provide innovative solutions for the development of the company.

On the other hand, from actual documentation we found that wages at CONF Ltd. are close to the minimum wage for the direct productive staff in the company, plus meal vouchers. This wage moderation measure has been taken to correlate wages with labor productivity so that they do not increase more than productivity. In the company, the history analysis has identified situations where it has been necessary to reduce the auxiliary staff in order to minimize the labor costs. In the same area of discussion, we show that the administrator CONF Ltd. does not have a management contract with monthly remuneration that would have resulted in a performance indicator based on the company's earnings, but on the basis of an ordinary employment contract, so that it benefits from a pre-established contractual salary.

A peculiarity of this company is that it operates in a rented space for which a convenient monthly rent is paid and which has brought many advantages to the business owner, among which the most important we consider to be the fast start of the initial production, without the need to realize the investment that took time. CONF Ltd. manages to reduce your costs by contracting the cheapest utilities providers (electricity, water, natural gas) and employing double qualified staff so as to make the least use of external services.

\section{Conclusions}

Therefore, we find that the cost-cutting strategy should be comprehensive, referring to the reduction of all types of costs, in all sectors of the company's activity, not just to reducing labor costs, as is the case with the most many companies. Through the reduction paths presented, we are of the opinion that CONF Ltd., manages to minimize the costs of the company through the activities it carries out.

The Direct Costing method using performance indicators for manufactured products was determined by fixed costs that provide stakeholder information on the equilibrium point, coverage factor, safety factor, and safety margin so that the company can plan the production of the goods and volume of sales to cover their revenues, expenses and no losses.

From the calculation of costs based on the production of direct-costing production for January 2018, the relevant results were obtained as a result of the direct-costing of the indicators. The study results from the costing perspective show that there is not a sufficiently high level of the profitability and the equilibrium point, which means that the company under consideration may be 
exposed to the risk of bankruptcy and financial imbalance if the volume of sales is lower than the safety margin of the difference between the turnover and the profitability threshold.

We also found that CONF Ltd. is trying to reduce its costs mainly by using customer samples, using leased halls to avoid using money resources in investment, and manufacturing clothings with a minimum of workforce.

\section{Acknowledgement}

This work is supported by project POCU 125040, entitled "Development of the tertiary university education to support the economic growth - PROGRESSIO", co-financed by the European Social Fund under the Human Capital Operational Program 2014-2020

\section{References}

1. Bistriceanu G., 2001. Lexicon de Finanţe, Bănci, Asigurări, Vol. I, Economică Publishing, Bucureşti, p. 461.

2. Bragg S., 2011. Cost Reduction Analysis: Tools and Strategies, Wiley Advisor Publishing, p. 7.

3. Briciu S., Căpuşneanu S., Căprariu A., 2013. Optimizarea profitului în condiţii de criză, Economie teoretică şi aplicată Jurnal, Vol. XX, No. 6 (583), p. 61.

4. Bunea-Bontaş C., 2013. The cost of production under Direct Costing and absorption costing - a comparative approach, Annals of the "Constantin Brâncuşi”" University of Târgu Jiu, Economy Series, Issue 2, p. 123.

5. Călin O., Man M., Nedelcu M.V., 2008. Contabilitate managerială, Didactică and Pedagogică RA Publishing, Bucureşti.

6. Căpuşneanu S., 2006. Contabilitatea de gestiune şi calculaţia costurilor. Studii aplicative şi teste grilă: Edition II, Economică Publishing, Bucureşti, p. 1.

7. Figar N., Ivanović V., 2015. Cost reduction strategy - process and effects, Facta Universitatis, Vol. 12, No. 1, p. 16.

8. Hada T., Avram T. M., 2018. Performance of manufactured and sold goods by direct costing method, International Conference "Risk in Contemporary Economy", Edition XIX.

9. Hada T., 1999. Finanțele agențiilor economici din România, Intelcredo Publishing, Deva, p. 205.

10. Ionescu I., 2013. Considerations regarding the purpose of direct costing method in a company management: Annals of the "Constantin Brâncuşi" University of Târgu Jiu, Economy Series, Issue 2, pp. 37-38.

11. Kulkarni M., Pandit A., 2014. Analysis of Cost Reduction Techniques Adopted in Hospitals in and Around Pune, Journal of Health Management, Vol. 16, No. 4, p. 482.

12. Samochiş B., Purdea D., (coordonatori), 2007. Economia întreprinderii, Risoprint Publishing, Cluj-Napoca, p. 97.

13. Sârbu J., 2005, Managementul producţiei, Risoprint Publishing, Cluj-Napoca, p. 105.

14. *** Nomenclature of economic activities - NACE codes, item 1413 - Manufacture of other articles of clothing (excluding underwear), 2017, Rev. 2.

15. *** Top companies in Romania Website, www.topfirme.com, item NACE 1413, accessed on 02.06.2019. 